\title{
The Role of Social Media in Voter Education in Nigeria
}

\author{
Ayeni Toba Paul* \\ Independent National Electoral Commission, Ado Ekiti, Nigeria
}

*Corresponding author: Ayeni Toba Paul, Independent National Electoral Commission, Ado Ekiti, Nigeria.

\author{
Received Date: October 29, 2018 \\ Published Date: January 24, 2019
}

\begin{abstract}
Social media has become a prominent and a powerful forum for voter enlightenment, political activism and fastest means of information dissemination. Social media platforms, such as Instagram, Twitter, Facebook and YouTube help to activate citizens' engagement in political life. The Independent National Electoral Commission (INEC) saddled with the responsibility of educating voters on their electoral roles and responsibilities unfortunately doesn't have pronounced presence in the social space. This paper analyses the roles of social media in voters' education and how INEC can make itself more active on the cyberspace for effective information dissemination and voter education.
\end{abstract}

Keywords: INEC; Social Media; Voter Education; Information Dissemination; Cyberspace

Abbreviations: INEC: Independent National Electoral Commission, FIRS: Federal Inland Revenue Service

\section{Introduction}

The use of social media in politics has continued to grow in recent times. Since Barack Obama broke the world record in the history of social media use for political purpose during the 2008 US presidential elections, many nations and politicians across the globe have continued to embrace the platform to mobilise their citizens and candidates towards active participation in the political process [1]. It was argued that four key stakeholders in the electoral process (the Independent National Electoral Commission (INEC), politicians/political parties, the electorate, and Civil Society Organizations) made extensive use of social media during the 2011 and the 2015 elections in Nigeria. Each of these stakeholders used the social media to achieve a number of interrelated objectives. Based on the arguments, it is concluded that social media platforms have fundamentally aided political communication in Nigeria [2].

\section{Role of Social Media in Political Awareness}

In a modern democracy, social media can be used by governments to involve citizens in decision making, and by civil society to engage people in specific issues. However social media can also be used to broaden political participation by helping citizens to communicate with their representatives and with each other [3] The use of social media as a formidable force for social engineering and political electioneering has continued to grow. The technology is participatory, interactive and cost-effective. This has made it the medium of the moment as far as political communication and participation are concerned [4]. The role of youth in electoral activities cannot be over emphasised. They play active role in mobilising support for candidates and actual voting. They are the active participants of election violence and also the active users of social media. Disseminating useful information to youth in form of voter education is a means of forestalling incidences of election violence and electoral manipulations. Data released by statista.com indicated that there are 84.3 million internet users in Nigeria and that by 2019, there would be 93 million internet users. Chukwuemeka Afigbe, Manager Developer programme at Facebook revealed that about 26 million Nigerians now login on Facebook every month. Social media is indeed the best avenue for reaching out to majority of the voters.

\section{INEC Presence in the Cyberspace}

Cyberspace is now critical to every nation's socio-economic, cultural and political activities. When it is disrupted or fails, a country may experience strong adverse effects. On the contrary, its correct functioning and pliability is transforming modern society 
with exceptional pecuniary and social benefits. With many activities increasingly moving to the Internet, cyberspace has become a new stage for innovations, enterprises, social networking, criminality and war [5] (Figure 1). The above diagram estimated INEC presence in the cyberspace to 0.615 . INEC is rated alongside Federal Inland Revenue Service (FIRS), Honeywell Company, Ericsson Nigeria and Interswitch while organizations like Central Bank of Nigeria, Arm Financial service, Arik air and Eko hotel were rated higher than INEC. None of the organization or parastatals rated alongside or above INEC in reality should be rated close to INEC who pride itself of 84million registered voters ahead of 2019 general election. No organization or parastatals can boast of such data; yet it seems INEC is not doing much to make itself more pronounced in the cyber space (Table 1) The table above compares the presence of INEC in the cyberspace with some organizations and personalities in Nigeria. Wizkid, a young Nigerian celeb and Bukola Saraki, a prominent politician both beat INEC in popularity and presence in the social space; whereas INEC with over 84 million voters in its database in reality is more popular than both. More works are needed to be done to improve INEC presence in the social space.

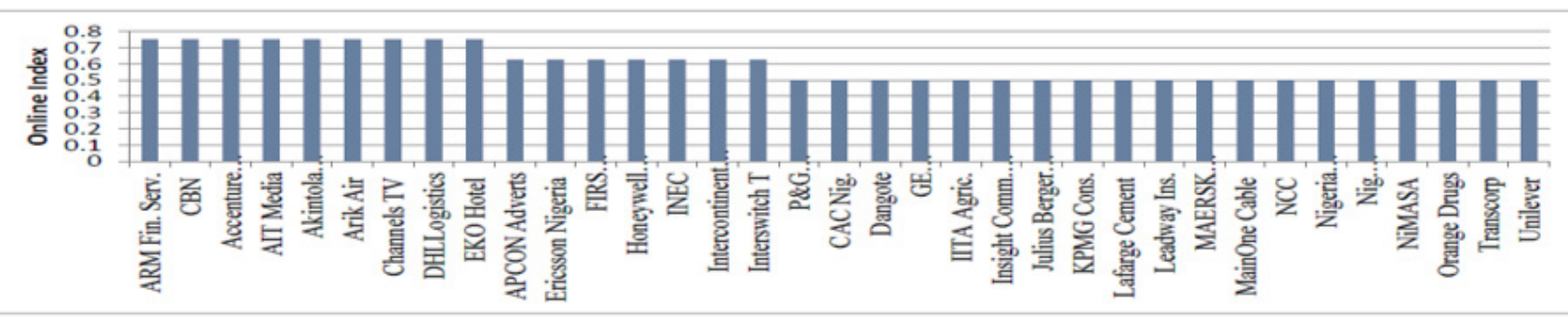

Figure 1: Online index for some multinationals and government.

Table 1: Comparing INEC presence in social space with selected organizations and personalities as at Friday, 36th October, 2018.

\begin{tabular}{|c|c|c|c|c|c|c|}
\hline & Social Media & INEC & Gtbank & Channels Tv & Wizkid & Bukola Saraki \\
\hline & & & (Commercial outfit) & (Media house) & (Celebrity) & (Politician) \\
\hline 1 & Facebook & 312,821 & 6.6 million & 1.23 million & 1.93 million & 529,440 \\
\hline 2 & Twitter & 1.04 million & 1.44 million & 3.06 million & 4.38 million & 1.39 million \\
\hline 3 & Instagram & 56,800 & 447,000 & 208,000 & 6.2 million & 275,400 \\
\hline 4 & YouTube & $49 ; 55$ videos & 20,$000 ; 236$ video & 229,000 & 433,000 & No Presence \\
\hline
\end{tabular}

\section{Recommendations}

The following recommendations are necessary to make INEC presence more pronounced in the cyber space:

\section{Post promotion}

Every post of INEC should hence forth be promoted on Facebook and Instagram to reach more people. The more people see INEC posts and either likes or comments on it, it boost INEC presence in the social space.

\section{Page promotion}

INEC should ensure it attracts nothing less than 10 million fans on Facebook and twitter before 2019 general election. This can be achieved by promoting INEC Facebook page through targeting. It has a financial implication though.

\section{Professionalism}

Handlers of INEC social media must be sound in Information Technology and proficient in English language. They must understand the workings and programmes of INEC and should be conversant with real life situation on the field i.e. in states and local government areas. They must be patient and mature enough to handle insults and abuses from aggrieved voters.

\section{Presence and engagement}

Handlers must always be online to attend to people's query or questions. Every post should be responded to within 2 minutes. The response could be in form of apologies, explanation, education or smiley. This would boost people confidence in INEC. INEC events can be transmitted live on social media. E.g. Facebook live, and YouTube live.

\section{Participation}

Every staff of INEC must be made to subscribe to INEC social media platforms. They should be actively involved in liking, commenting and sharing posts from INEC.

\section{Presentation}

Simple and short posts with clarity, void of ambiguity. Clear and quality pictures with clear descriptions should always be posted.

\section{Conclusion}

As a commission that is planning to go fully electronic in few years to come, INEC cannot afford to have a limited presence in the cyber space. It should rise to use the many dividend of technology to its advantage. It is believed that social media can help reduce costs of educating voters and getting them acquainted with INEC plans and programmes.

\section{Acknowledgement}

None.

\section{Conflict of Interest}

No conflict of interest. 


\section{References}

1. Onyedikachi Madueke, Celestine Nwosu, Chibuzo Ogbonnaya, Adaeze Anumadu (2017) The Role of Social Media in Enhancing Political Participation in Nigeria.

2. Okechukwu Chukwuma (2018) A Discursive Analysis of Social Media Usage for Political Communication in Nigeria. International Journal on Transformations of Media Journalism \& Mass Communication 3(1).
3. Davies R (2014) Social Media in Election Campaigning. A Publication of the European Parliamentary Research Service. pp 1-8.

4. Okoro MN, Adibe KN (2013) Social media and political participation in Nigeria during the 2011 general elections: the lapses and the lessons. Global Journal of Arts Humanities and Social Sciences 1(3): 29-46.

5. Uche M, Mbanaso, GA Chukwudebe, EE Atimati (2015) Nigeria’s evolving presence in cyberspace. 